\title{
DELAVNICA ZA MOŠKE IN ŽENSKE ALI S TRESORJEM DO POSLOVNE PROSVETLENOSTI
}

\author{
Dušana Findeisen
}

"Spoštovani, prva številka Tresorja je izšla in podjetja v vaši okolici že izkoriščajo znanje, ki se ga dobi v niemu. Da lahko dobite boljši občutek o tem, kako izgleda Tresor... Č menite, da bo tresor koristen tudi za vaš uspeh, nam pošljite naročilnico... da vam lahko zagotavljamo, da boste dobili naslednjo stevilko pravočasno. Želimo vam prijetno branje, za boljsi uspeh.«Podpisan mag XY. Pa še tole pojasnilo: Tresor je »mesečna delavnica namenjena za boljš učinkovitost, orodje, $k i$ je namenjeno tako moškim kot ženskam v poslovnem svetu«.

Teh nekaj uvodnih misli iz spremnega pisma in iz prve številke Tresorja, imenovane kar Issue 1 , nas bo zagotovo popeljalo v svet ameriškega poslovanja in trženja, in to za borih 4800 tolarjev letno (od izdelka pa je treba plačati le pet odstotkov davka!). Za ta denar boste prejeli približno triintrideset strani razprtega besedila, ki ga prevajalci ali morda tudi avtorji v svojem neznanju imenujejo »delavnica za ženske in moske v poslovnem svetu«. Nastajanje novih podjetij v tržno usmerjenem gospodarstvu je $v$ Sloveniji še zmeraj na začetnih stopnjah (obeta se nam torej dolg začetek!), tako da nam lahko ameriške izkušnje dajo približno idejo o tem, kaj lahko naša mala podjetja pričakujejo, vam povedo v Tresorju.

In kdo postane podjetnik? Ker je bilten prilagojen slovenskemu poslovnemu prostoru, je podjetniku seveda ime Janez in Janez je tako kot večina ljudi, ki se podajo na svoje, opravljal tehnično delo - pisal je računalniške programe. Ce bi pogledali v statistične podatke Zavoda za zaposlovanje, bi ugotovili, da to nikakor ne drži, da se pri nas podjetništva lotevajo ljudje na najrazličnejših področjih, tudi na takih, ki v samem začetku niso $\mathrm{v}$ povezavi $\mathrm{z}$ njihovimi dotedanjimi izkušnjami. S te prve strani Issue 1 boste pridobili bistveno spoznanje, da uspeh $v$ spretnosti ne pomeni uspeha $v$ posiu. Za tiste, ki dobro obvladamo anglesski jezik, ta misel morda ne bo tako trd oreh, saj si jo bomo prevedli nazaj v angleščino, pa bo nakako šlo. Drugače povedano torej, če znamo opravljati delo na svojem strokovnem področju, to še ne pomeni, da bomo tudi poslovno uspešni. V Tresorju nam povedo, da bomo poleg teh spretnosti morali obvladovati tudi druge in da nam ne bo lahko. (Mimogrede še to, nič več, tako se zdi, ni potrebno znanje, potrebne so le spretnosti!).

$\mathrm{Na}$ drugi strani (ali pol strani) zvemo nekaj več o podjetniku Janezu. Najprej o tem, kakšna naj bo podjetnikova osebnost, vse pod naslovom $\gg$ Osebnostni profil - razkriva osnovni značaj« (čigav značaj?). Podjetnik naj ima zagon (beri moč ali kaj podobnega!), naj bo motiviran, naj obvlada sporazumevanje $\mathrm{z}$ drugimi, naj ima odločenost, tako da v težavah ne odstopi... kadar je potrebno, je lahko samozavesten (beri zna biti samozavesten!). Osebnostne lastnosti pa niso dovolj, tudi nekaj pozitivnih poklicnih lastnosti bo Janez potreboval. Nasvete o teh bo našel pod naslovom »Poklicni profil - razkriva zvestobo in zanesljivost " (beri v poklicu naj bo podjetnik zvest svojim odločitvam in zanesljiv). Opravi naj svoje obveze... uporablja vpliv (čigav) za dosego svojih ciljev. Imeti mora tudi spretnosti poslušanja (beri mora znati prisluhniti drugim). Tu pa se modre misli druge strani še ne končajo. Zvemo, da so podjetniku poleg osebnostnih lastnosti in nekaterih poklicnih lastnosti potrebne še tiste, ki jih bralec najde pod naslovom "Poslovni profil - razkriva razumevanje tega, da ste $v$ poslu zaradi dobička«.

Na zadnji polovični strani se boste lahko zamislili ob vprašanjih Ali imate v svojem poslu podjetnikovo gledanje? in Ali pa imate v svojem podjetju tehnikovo gledanje? Obveščn bralec bo $\mathrm{z}$ velikim trudom nekako izlušcil 120 tolarjev vredno misel, da se v podjetju ne osredotočamo na posel, ne da bi razmišljali o tem, komu je namenjen, torej kakšnim strankam. Skratka, posel so ljudje!

Pisati recenzijo takšne pridobitniško naravnane spakedranščne ni lahka naloga. Težko je izluščiti kaj dobrega, uporabnega. Spodbudna pa je oblika biltena: dvobarvna naslovnica, lepo oblikovane črke, učinkovito prelomljena stran. Oblikovna plat je tako povsem $\mathrm{v}$ nasprotju $\mathrm{z}$ neprofesionalnostjo vsebine. Ta se kaže v skoraj dialektalni govorici, v neanalitičnosti prevajalčeve misli, ko prehaja iz ene jezikovne kode v drugo, pri čemer ne ve, da obstojajo kompaktne sintagme, ki jih je moč nadomeščati $z$ drugimi v drugem jeziku, le če nas pri tem vodita razvit analitični duh in seveda poklicna izkušenost. Bilten je tudi pravo nasprotje dobrega prevoda ali dobre priredbe ameriškega pisanja, seveda ne takšnega, ki bi mu bila podlaga tehten strokovni premislek. Podjetje, ki pošilja bilten Tresor med znanja željno bralstvo, se verjetno zaveda, da je treba nastopati tržno (to je tudi vodilna misel prve številke), povsem pa zanemarja drugo plat, ki jo poimenuje "tehnična plat posla«, čemur bi lahko rekli kar strokovnost.

Ta stroka naj bi bila izobraževanje. Kot uvodni poduk povejmo »avtorjem prirejevalcem«, kaj je delavnica. Vsekakor ne list ali dva popisanega papirja. Delavnica je izobraževalna oblika, kjer se udeleženci ali študentje učijo izkustveno in skupaj, v majhni skupini. V takšni delavnici mentor učenje vodi, tako da prihaja do neprestanega menjavanja izkušenj in spoznanj udeleženih, do za učenje in osebnostno rast spodbudnih medosebnih razmerij in do končnega izdelka. Gre za učenje $z$ delom. $V$ stroki ta pojem pojasnjujejo nekateri avtorji, npr. John Holt v delu Namesto izobraževanja. Morda bi avtorjem prirejevalcem biltena John Holt lahko odprl prvi pogled v izobraževanje, stroko, ki si jo $z$ neukimi šapami lastijo. $\mathrm{Pa}$ se nekaj: iztrgati pojme iz drugega sveta in jih vsaditi $v$ našega je nevarno. Č že, pa so za to potrebne izkušnje, dosti znanja ter presoje.

* Opomba: besedilo v kurzivi so citati. 